
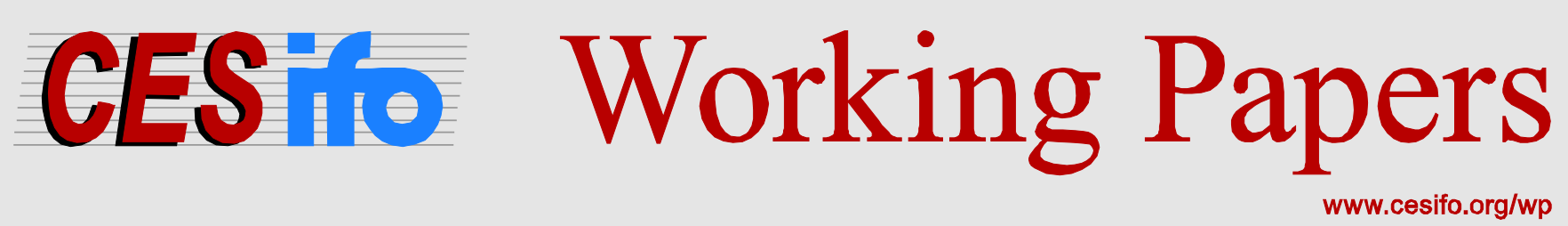

\title{
The Sovereign Default Problem in the Eurozone: An Insurance-Based Approach
}

\author{
Nadjeschda Katharina Arnold \\ Ray Rees
}

\author{
CESIFO WORKING PAPER NO. 5389 \\ CATEGORY 6: Fiscal POLICY, MACROECONOMICS AND GROWTH \\ JUNE 2015
}
An electronic version of the paper may be downloaded
- from the SSRN website:
- from the RePEc website:
- from the CESifo website:
www.SSRN.com
www.RePEc.org
www.CESifo-group.org/wp




\title{
The Sovereign Default Problem in the Eurozone: An Insurance-Based Approach
}

\begin{abstract}
This paper argues that the Eurozone crisis stems from a risk management failure in the Eurosystem's design, and that applying insurance theory is useful. We model risk neutral agents choosing portfolios of government bonds of $n$ countries in a monetary union and other assets. We firstly analyse a country's debt choice, assuming as a benchmark case that the no-bailout threat is credible, accounting for the effect on its equilibrium interest rate, and then establish an equally efficient mutual insurance fund covering accruing indemnities almost certainly. We also discuss necessary institutional arrangements and other proposals in the light of our results.
\end{abstract}

JEL-Code: G110, G120, G220, H630, H770.

Keywords: European debt crisis, sovereign debt, bailout, monetary union, debt management.

\author{
Nadjeschda Katharina Arnold \\ Department of Economics \\ CES, University of Munich \\ Schackstrasse 4 \\ Germany - 80539 Munich \\ nadjeschda.arnold@econ.lmu.de
}

\author{
Ray Rees \\ Professor Emeritus \\ Faculty of Economics \\ University of Munich \\ Munich / Germany \\ Ray.Rees@lrz.uni-muenchen.de
}

28 May 2015 


\section{Introduction}

The current crisis in the Eurozone, created by the problem of sovereign debt defaults, the conflicts about "bailouts" together with the debate about construction of "bailout funds" and a "banking union" stem from a basic failure of risk management in the initial design of the Eurosystem, the failure to take account of the question:

What arrangements should be put in place to deal with the risk of sovereign debt defaults taking place in some states of the world with positive probability?

The approach of trying to place constraints on risky actions of Eurozone countries as stipulated by the Maastricht Treaty, for example on the choice of public sector deficits, is clearly inadequate because it lacks credible incentives and punishments. Likewise, the promise not to bail out countries ex post as stated in the "no-bailout clause" of that treaty is also inadequate, as economic agents in financial markets do not see the promise as credible. The recent experience simply leaves a legacy of ambiguity and uncertainty about the extent to which "haircuts" may be demanded or bailouts granted.

This paper argues that a more fruitful approach is to draw on the economics of insurance markets to provide a conceptual basis for the design of the $\mathrm{Eu}$ rosystem that will deal with this problem in the future.

In our model, we consider $n$ countries in the world economy. The countries have already formed a monetary union and so have a common currency. Thus there is no exchange rate risk. The only source of risk is the possibility of a default in one or more of the countries. All countries' governments issue sovereign debt so as to maximise expected national welfare or, since citizens are assumed to be risk neutral, expected national income. Investors who reside all over the world choose portfolios containing the countries' debt as well as other assets so as to maximise their expected income.

We analyse and compare the debt levels, the interest rates and welfare for two situations: the counterfactual benchmark case in which we assume that the threat of no bailouts is fully credible, and a case in which we show that a mutual insurance fund can be established that is just as good in terms of efficiency and covers indemnities arising out of sovereign debt defaults almost certainly. It turns out that countries choose the optimal levels of debt in both situations and that only the countries' interest rates differ. The countries choose the optimal debt levels as they have to compensate either, in the first case, the investors, in form of interest rate risk premia or, in the second case, the mutual insurance fund by payment of their insurance premia. Their interest rates differ across the two situations exactly by their interest rate risk premia.

The main conclusion of the paper is therefore that an appropriately designed mutual insurance scheme against the risk of sovereign debt default, where premia are risk-based, is effectively equivalent to a system in which the no-bailout promise is fully credible. The insurance premia replace the risk premia on interest rates that would prevail if investors fully believed in the no-bailout

commitment. An important aspect of the insurance scheme therefore is that it eliminates the ambiguity that persists under purely bond-based proposals of the 
kinds that have been made recently, and which are further discussed below. It also removes the risk of the kind of political and economic crises that have been observed to follow when sovereign debt defaults, or the imminent occurrence of them, have to be dealt with ex post in an ad hoc way. Finally, it avoids the political controversy and inflation risks involved in a "whatever it takes" type of solution through the central banking system.

The simple form of insurance model we present here should not be taken too literally. Once we clarify the principles of the mutual insurance fund we will deal with the possibilities of "realistic" implementation and the institutional arrangements necessary for that. Finally, we will explain why currently popular proposals such as: the European Stability Mechanism, Eurobonds, a distinction between "blue" and "red" bonds (Bruegel, 2010), debt repayment funds (German Council of Economic Experts, 2011), "stability bonds" (European Commission, 2011), partial sovereign bond insurance by the European Stability Mechanism (Dübel, 2011), and a multi-stage crisis mechanism (EEAG, 2011) are not appropriate tools to stabilise and structure the sovereign debt problem in the euro area in the light of our analysis. Basically, all these proposals are missing ex ante compensation for the aid that they offer in case of default, thus, if implemented, further boosting the accumulation of sovereign debt in the Eurozone and contributing to an additional destabilisation of its situation. The opposite is true for our insurance approach, which in this form has not yet been put forward for dealing with the problem of sovereign debt defaults (especially not in a formal way!), and therefore can be considered as new and pioneering for tackling the crisis in the Eurozone.

Though the insurance idea is original to this paper, there is a related body of research, in particular the literature on the role of commitment problems in debt accumulation, including contributions on monetary unions (e.g. Beetsma \& Bovenberg, 1999; Beetsma \& Uhlig, 1999; Chari \& Kehoe, 2007 and 2008; Cooper \& Kempf, 2004; Cooper et al., 2010; Uhlig, 2003) and fiscal federalism (e.g. Cooper et al., 2008; Crivelli \& Staal, 2013; Goodspeed, 2002; Wildasin, 1997). Our insurance approach is motivated by the excessive incentives to accumulate debt arising from the commitment problem to no bailouts in a monetary union. ${ }^{1}$ Similar commitment problems exist in the literature on central bank control of inflation in a monetary union, and in the fiscal federalism literature. Our model differs from these in that uncertainty plays a central role to the idea of an insurance solution.

\section{Sovereign Debt Accumulation in a Monetary Union: The Model}

This paper argues that the problem of sovereign debt defaults in the Eurozone is basically one of risk management and that the establishment of a mutual

\footnotetext{
${ }^{1}$ Concerning the mathematical derivation compare Arnold (2014), Chapter 3. Intuitively, countries choose too high debt levels because they do not have to compensate anybody for their risk ex ante.
} 
insurance fund is the most appropriate solution. Here we present the model on which the argument is based.

\subsection{Overview}

We consider the governments of $n$ countries in the world economy constituting a monetary union and investors residing all over the world, demanding and supplying capital on the world capital market so as to maximise their respective utilities.

Each country's government borrows money on the world capital market by issuing bonds at a nominal interest rate $r_{i}, i=1, \ldots n$, so as to maximise expected national welfare or, since citizens are assumed to be risk neutral, expected national income. Concretely, the governments employ the capital in the production of goods, for example undertake public investment in infrastructure, education and health services, which benefit their populations of consumers.

The production process involves uncertainty and is described by

$$
Y_{i}=\int_{\theta_{i}^{0}}^{\theta_{i}^{1}} Y_{i}\left(D_{i}, \theta_{i}\right) d F_{i}\left(\theta_{i}\right) i=1, \ldots n
$$

where $Y_{i}$ is real production and $D_{i}$ is capital $=$ nominal debt. The parameter $\theta_{i} \in\left[\theta_{i}^{0}, \theta_{i}^{1}\right]$ with cumulative distribution function $F_{i}\left(\theta_{i}\right)$ introduces uncertainty. The production function $Y_{i}(\cdot)$ satisfies the Inada conditions. ${ }^{2} Y_{i}$ is therefore increasing at a decreasing rate in $D_{i}$ for given $\theta_{i} ; Y_{i}$ and $\partial Y_{i} / \partial D_{i}$ are increasing in $\theta_{i}$ for given $D_{i}$. We assume throughout the discussion of the model that the countries' risks as expressed by the $F_{i}\left(\theta_{i}\right)$ are statistically independent. The implementation of the type of system we are proposing would of course require correlation of risks to be taken into account. This is a standard issue in insurance economics.

A country suffers a default if the productivity of the government's investment turns out to be so low that it cannot repay its debt plus interest,

$$
Y_{i}\left(D_{i}, \theta_{i}\right)<\left(1+r_{i}\right) D_{i} \quad i=1, \ldots n
$$

The default probability of country $i$ is then defined as

$$
\delta_{i}=\int_{\theta_{i}^{0}}^{\hat{\theta}_{i}} d F_{i}\left(\theta_{i}\right)=F_{i}\left(\hat{\theta}_{i}\right) \quad i=1, \ldots n
$$

where $\hat{\theta}_{i}$ is a critical value of $\theta_{i}$ that satisfies

$$
Y_{i}\left(D_{i}, \hat{\theta}_{i}\right)-\left(1+r_{i}\right) D_{i}=0
$$

\footnotetext{
${ }^{2}$ The Inada conditions for the production function $Y_{i}(\cdot)$ are: [1] $Y_{i}\left(D_{i}=0\right)=0,[2] Y_{i}(\cdot)$ is continuously differentiable in $D_{i},[3] \frac{\partial Y_{i}}{\partial D_{i}}>0$, [4] $\frac{\partial^{2} Y_{i}}{\partial D_{i}^{2}}<0,[5] \lim _{D_{i} \rightarrow 0} \frac{\partial Y_{i}}{\partial D_{i}}=+\infty$, and [6] $\lim _{D_{i} \rightarrow+\infty} \frac{\partial Y_{i}}{\partial D_{i}}=0$. Compare Inada (1963).
} 
$\hat{\theta}_{i}$ is therefore an implicit function of $r_{i}$ and $D_{i}$. From the Implicit Function Theorem it follows that

$$
\begin{gathered}
\frac{\partial \delta_{i}}{\partial D_{i}}=f_{i}\left(\hat{\theta}_{i}\right) \frac{\partial \hat{\theta}_{i}}{\partial D_{i}}=-f_{i}\left(\hat{\theta}_{i}\right)\left(\frac{\partial Y_{i}\left(D_{i}, \hat{\theta}_{i}\right)}{\partial D_{i}}-\left(1+r_{i}\right)\right) / \frac{\partial Y_{i}\left(D_{i}, \hat{\theta}_{i}\right)}{\partial \theta_{i}} \\
\frac{\partial \delta_{i}}{\partial r_{i}}=f_{i}\left(\hat{\theta}_{i}\right) \frac{\partial \hat{\theta}_{i}}{\partial r_{i}}=f_{i}\left(\hat{\theta}_{i}\right) D_{i} / \frac{\partial Y_{i}\left(D_{i}, \hat{\theta}_{i}\right)}{\partial \theta_{i}}>0
\end{gathered}
$$

The default probability increases with the debt level if the marginal product of debt, $\partial Y_{i} / \partial D_{i}$, in state $\hat{\theta}_{i}$ is less than the rate of return that has to be paid on it, $1+r_{i}$ (this is fulfilled with the Inada conditions), while an increase in the interest rate always increases default risk.

If country $i$ defaults, it can either renege on its total debt or repay debt to the extent it is able to. The proportion $\gamma_{i}$ of debt claims that country $i$ is able to repay in case of default satisfies

$$
\gamma_{i}\left(1+r_{i}\right) D_{i}-Y_{i}\left(D_{i}, \theta_{i}\right)=0
$$

$1-\gamma_{i}$ models the "haircut", in that it gives the proportion of debt claims that are not met given default. From the Implicit Function Theorem it follows that, for $\gamma_{i} \in(0,1)$,

$$
\begin{gathered}
\frac{\partial \gamma_{i}}{\partial D_{i}}=-\left[\gamma_{i}\left(1+r_{i}\right)-\frac{\partial Y_{i}\left(D_{i}, \theta_{i}\right)}{\partial D_{i}}\right] /\left[\left(1+r_{i}\right) D_{i}\right] \\
\frac{\partial \gamma_{i}}{\partial \theta_{i}}=\frac{\partial Y_{i}\left(D_{i}, \theta_{i}\right)}{\partial \theta_{i}} /\left[\left(1+r_{i}\right) D_{i}\right]>0 \\
\frac{\partial \gamma_{i}}{\partial r_{i}}=-\gamma_{i} D_{i} /\left[\left(1+r_{i}\right) D_{i}\right]<0
\end{gathered}
$$

Thus, the proportion of debt claims that are met given default decreases with the debt level if the marginal product of debt in state $\theta_{i}$ is less than its remuneration (this, too, is fulfilled with the Inada conditions), while it always increases with the productivity and decreases with the interest rate.

Each investor has an initial wealth level $W^{0}$ and lends money through the world capital market by buying either government bonds of the $n$ countries or investing elsewhere in the world economy at the risk free interest rate $\bar{r}$ so as to maximise her expected income. For simplicity, the investors who reside in country $i=1, \ldots n$ are assumed to benefit only from private investment. They are not consumers, i.e. they are neither beneficiaries nor bearer of costs with regard to public investment. Moreover, they neither pay for potential bailouts nor bear the costs of insurance-here, it is the consumers who foot the bill.

The world capital market is characterised by perfect competition. The bond issues of the $n$ countries are assumed to be small compared to the volume of 
other investment possibilities and investors many in number so that governments and investors act as price takers, i.e. take the risk free interest rate $\bar{r}$ as given.

The sequence of actions is as follows: In stage 1, governments issue bonds; in stage 2, investors buy these bonds or invest elsewhere in the world economy; in stage 3, after the governments have invested the capital in goods production, the veil of uncertainty is lifted, i.e. the productivity parameters are realised.

We consider and compare the cases of a credible no-bailout policy and a mutual insurance fund, and show that they are formally equivalent, except in respect of the interest rates that individual countries pay in equilibrium. In the case of a credible no-bailout policy, investors are faced with a haircut if there is a sovereign debt default; in the case of a mutual insurance fund countries pay risk-related insurance premia into a mutual fund, from which they receive indemnities in case of default sufficient to pay off debt and prevent a haircut for the investors in their bonds. As a separate transaction, countries also provide reserves intended to meet fluctuations in aggregate claims above their expected value. These are invested at the risk-free market rate of interest, so countries' subscriptions to reserves are decoupled from the insurance premia they pay. ${ }^{3}$

We solve the model by backward induction for the case of a credible nobailout policy in Subsection 2.2 and for the case of a mutual insurance fund in Subsection 2.3. These solutions are compared in Subsection 2.4. The section ends with an explanation of the role of reserve payments in the case of a mutual insurance fund.

\subsection{Credible No-Bailout Policy}

In this case investors expect that they will suffer a haircut if they buy government bonds of countries in the monetary union and one or more of them suffers a default. This not only has an effect on their required interest rates but also on the governments' debt levels since governments, because of the assumed time structure, anticipate the behaviour of investors. We consider two possible scenarios: in the first, the country simply defaults on its entire debt if it cannot repay any of it. In the second, it repays whatever it can and defaults on the rest. Provided it is certain ex ante which of these scenarios will prevail, there is no essential difference in the results, though of course the insurance or risk premia will differ between the two scenarios. We obtain the specific effects by solving the model backward.

In stage 2 , each investor invests in government bonds of country $i=1, \ldots n$ or elsewhere in the world economy so as to maximise her expected income. Concretely, she chooses holdings $b_{i}$ in country $i$ bonds, $i=1, \ldots n$, while the capital that she invests in other assets is determined as residual of her initial wealth level $W^{0}$. If countries renege on their total debt in case of default, her

\footnotetext{
${ }^{3}$ These reserves, standard in the insurance world, are usually called "underwriting reserves" and are necessary because the variance of a sum of $n$ random variables, here the loss claims, is positive and increases with $n$, while "fair premia" of the kind considered here give premium income equal to the expected value of the sum.
} 
expected income or end of period wealth level is given by

$$
\bar{W}=\sum_{i=1}^{n}\left[1-\delta_{i}\right]\left(1+r_{i}\right) b_{i}+(1+\bar{r})\left[W^{0}-\sum_{i=1}^{n} b_{i}\right]
$$

and if they repay debt to the extent they are able to,

$$
\bar{W}=\sum_{i=1}^{n}\left[1-\delta_{i}+\int_{\theta_{i}^{0}}^{\hat{\theta}_{i}} \gamma_{i}\left(\theta_{i}\right) d F_{i}\right]\left(1+r_{i}\right) b_{i}+(1+\bar{r})\left[W^{0}-\sum_{i=1}^{n} b_{i}\right]
$$

The First Order Conditions (FOCs) imply that an interior solution of the portfolio choice problem requires, respectively

$$
\left[1-\delta_{i}\right]\left(1+r_{i}\right)=1+\bar{r} \quad \forall i
$$

or

$$
\left[1-\delta_{i}+\int_{\theta_{i}^{0}}^{\hat{\theta}_{i}} \gamma_{i}\left(\theta_{i}\right) d F_{i}\right]\left(1+r_{i}\right)=1+\bar{r} \quad \forall i
$$

i.e. we have an arbitrage condition on the equivalence of expected interest payments. The optimal bondholdings are any $b_{i} \in\left[0, W^{0}\right], \forall i$, with $\sum_{i=1}^{n} b_{i} \leq$ $W^{0}$, and the expected end of period wealth is $\bar{W}=(1+\bar{r}) W^{0}$.

In stage 1 , each country's government issues bonds, i.e. chooses its debt level $D_{i}, i=1, \ldots n$, so as to maximise its expected national income anticipating the portfolio choice of investors. The expected national income of country $i$, if it reneges on its total debt in case of default, is given by

$$
\bar{G}_{i}=\bar{W}_{i}+\int_{\theta_{i}^{0}}^{\theta_{i}^{1}} Y_{i}\left(D_{i}, \theta_{i}\right) d F_{i}-\left[1-\delta_{i}\left(D_{i}\right)\right]\left(1+r_{i}\right) D_{i}
$$

and if it repays debt to the extent it is able to,

$$
\bar{G}_{i}=\bar{W}_{i}+\int_{\hat{\theta}_{i}}^{\theta_{i}^{1}} Y_{i}\left(D_{i}, \theta_{i}\right) d F_{i}-\left[1-\delta_{i}\left(D_{i}\right)\right]\left(1+r_{i}\right) D_{i}
$$

where $\bar{W}_{i}=(1+\bar{r}) W_{i}^{0}$ denotes the expected income of investors who reside in country $i$ and in sum have an initial wealth level of $W_{i}^{0}$.

Conditions (13) or (14), respectively, simplify this objective function to

$$
\bar{G}_{i}=\bar{W}_{i}+\int_{\theta_{i}^{0}}^{\theta_{i}^{1}} Y_{i}\left(D_{i}, \theta_{i}\right) d F_{i}-(1+\bar{r}) D_{i}
$$

in either case, so that the FOC is given by

$$
\int_{\theta_{i}^{0}}^{\theta_{i}^{1}} \frac{\partial Y_{i}}{\partial D_{i}} d F_{i}=1+\bar{r}
$$


As $1+\bar{r}=\left[1-\delta_{i}\right]\left(1+r_{i}\right)$ and $\left[1-\delta_{i}+\int_{\theta_{i}^{0}}^{\hat{\theta}_{i}} \gamma_{i}\left(\theta_{i}\right) d F_{i}\right]\left(1+r_{i}\right)$, respectively, country $i$ pays debt, in expectation, according to its expected marginal product. The optimal debt level is implicitly determined by (18). From the Implicit Function Theorem it follows that

$$
\frac{\partial D_{i}}{\partial \bar{r}}=1 / \int_{\theta_{i}^{0}}^{\theta_{i}^{1}} \frac{\partial^{2} Y_{i}}{\partial D_{i}^{2}} d F_{i}<0
$$

The optimal debt level of country $i$ decreases with the risk free interest rate $\bar{r}$. The expected welfare of country $i$ is given by (17) whereby $D_{i}$ is implicitly determined by (18).

\subsection{Mutual Insurance Fund}

Now countries pay insurance premia into a fund from which they receive indemnities in case of default, which prevent a haircut for the investors in their bonds. Investors take the insurance into account when they choose their portfolio, i.e. specify the interest rates for which they are willing to buy government bonds. Moreover, insurance affects the governments' debt decision as governments anticipate the behaviour of investors due to the selected time structure. Before we derive the specific effects by backward solution we specify the elements of the mutual insurance fund.

We consider a mutual insurance fund that offers full insurance in the form of an indemnity that covers a country's haircut in the event of default for a fair

premium. The indemnity function, if country $i$ reneges on its total debt in case of default, is therefore given by

$$
I_{i}=\left\{\begin{array}{cll}
\left(1+r_{i}\right) D_{i} & \text { if } & \theta_{i}<\hat{\theta}_{i} \\
0 & \text { if } & \theta_{i} \geq \hat{\theta}_{i}
\end{array}\right.
$$

and if it pays debt to the extent it is able to,

$$
I_{i}=\left\{\begin{array}{ccc}
\left(1+r_{i}\right) D_{i}-Y_{i}\left(D_{i}, \theta_{i}\right) & \text { if } & \theta_{i}<\hat{\theta}_{i} \\
0 & \text { if } & \theta_{i} \geq \hat{\theta}_{i}
\end{array}\right.
$$

As the insurance premium is fair, it is equal to the expected value of the indemnity,

$$
\pi_{i}=\int_{\theta_{i}^{0}}^{\theta_{i}^{1}} I_{i}\left(D_{i}, \theta_{i}\right) d F_{i}
$$

Thus, the insurance premium, if country $i$ reneges on its total debt in case of default, is given by

$$
\pi_{i}=\delta_{i}\left(D_{i}\right)\left(1+r_{i}\right) D_{i}
$$

and if it pays debt to the extent it is able to, 


$$
\pi_{i}=\delta_{i}\left(D_{i}\right)\left(1+r_{i}\right) D_{i}-\int_{\theta_{i}^{0}}^{\hat{\theta}_{i}} Y_{i}\left(D_{i}, \theta_{i}\right) d F_{i}
$$

In stage 2 , each investor chooses holdings $b_{i}$ in country $i$ bonds, $i=1, \ldots n$, so as to maximise her expected income that is certain and given by

$$
\bar{W}=\sum_{i=1}^{n}\left(1+r_{i}\right) b_{i}+(1+\bar{r})\left[W^{0}-\sum_{i=1}^{n} b_{i}\right]
$$

The FOCs imply that an interior solution of the portfolio choice problem requires

$$
1+r_{i}=1+\bar{r} \quad \forall i
$$

i.e. the equivalence of interest rates. The optimal bondholdings are again $b_{i} \in\left[0, W^{0}\right], \forall i$, with $\sum_{i=1}^{n} b_{i} \leq W^{0}$, and the certain end of period wealth is $\bar{W}=(1+\bar{r}) W^{0}$.

In stage 1 , each country's government chooses its debt level $D_{i}, i=1, \ldots n$, so as to maximise its expected national income anticipating the portfolio choice of investors and taking into account the effect of its choice of debt on its insurance premium. The expected national income of country $i$, if it reneges on its total debt in case of default, is given by

$$
\bar{G}_{i}=\bar{W}_{i}+\int_{\theta_{i}^{0}}^{\theta_{i}^{1}} Y_{i}\left(D_{i}, \theta_{i}\right) d F_{i}-\left[1-\delta_{i}\left(D_{i}\right)\right]\left(1+r_{i}\right) D_{i}-\pi_{i}
$$

and if it repays debt to the extent it is able to,

$$
\bar{G}_{i}=\bar{W}_{i}+\int_{\hat{\theta}_{i}}^{\theta_{i}^{1}} Y_{i}\left(D_{i}, \theta_{i}\right) d F_{i}-\left[1-\delta_{i}\left(D_{i}\right)\right]\left(1+r_{i}\right) D_{i}-\pi_{i}
$$

Condition (26) and equations (23) and (24), respectively, simplify the objective function again to

$$
\bar{G}_{i}=\bar{W}_{i}+\int_{\theta_{i}^{0}}^{\theta_{i}^{1}} Y_{i}\left(D_{i}, \theta_{i}\right) d F_{i}-(1+\bar{r}) D_{i}
$$

in either case so that the FOC is again given by

$$
\int_{\theta_{i}^{0}}^{\theta_{i}^{1}} \frac{\partial Y_{i}}{\partial D_{i}} d F_{i}=1+\bar{r}
$$

Since $1+\bar{r}=1+r_{i}$, similar to the case of a credible no-bailout policy, debt is paid according to its expected marginal product, the slight difference being that it is paid that way not only in expectation but for all realisations of productivity. The optimal debt level is the same as in the previous case and again decreases 
with the risk free interest rate $\bar{r}$; the expected welfare also remains unchanged compared to the case before.

\subsection{Comparison of Credible No-Bailout Policy and $\mathrm{Mu}-$ tual Insurance Fund}

In the last two subsections we showed that countries choose the same debt levels in the cases of a credible no-bailout policy and a mutual insurance fund. Note that they also choose the efficient levels of debt as their FOCs imply the equivalence of expected marginal products in either case. Consequently, a credible no-bailout policy and full insurance are not only equally good but also first best in terms of efficiency. The reason the countries choose the optimal debt levels is that they have to internalise the costs of the risk of a default that they create by choice of their debt level. In the case of a credible no-bailout policy, the costs in case of default are borne by the investors; the countries have to compensate them for their risk in terms of an interest rate risk premium. In the case of full insurance, the bearer of costs in case of default is the mutual insurance fund; the countries have to compensate it for their risk in terms of an insurance premium. As countries have to compensate someone for their risk they are forced to internalise its costs and no market failure arises.

Note that the assumption of risk neutral investors leads to an underestimate of the benefits of the insurance solution. Under a credible no-bailout rule investors bear the default risk, whereas under the mutual insurance arrangement they do not. If investors are risk averse the insurance pool would do an even better job than the no-bailout rule since it also implies gains from risk reduction.

\subsection{The Need for Reserves under an Insurance Scheme}

The sum of claims in any one period is a random variable, the realised value of which in any given period may exceed premium income in that period. Thus reserves must be provided that reduce the probability of the insurance fund not being able to meet claims to almost zero. However, the subscription of these funds are in this model not a real cost since they can be held in the form of riskless bonds earning the market rate $\bar{r}$. They can be raised by the Eurozone countries, possibly as lump-sum contributions that are equal for all countries, or possibly as Eurobonds, or as specific liabilities of the insurance agency (see below). In insurance economics it is a standard proposition that, by the Weak Law of Large Numbers, as the number of insureds $n \rightarrow \infty$ the value of these required reserves per insured tends to zero, which in ordinary insurance markets represents a form of economy of scale. In the present case however, it is very unlikely that the number of Eurozone countries will ever be sufficiently large that the cost of reserves per country would be approximately zero. However, the key aspect of the model presented above is that the premium a country pays should reflect only its default risk. As just suggested, required reserves can be raised in a way that leaves this premium unaffected. In that sense the present model differs from the standard analysis of an insurance market. Note however 
that care must be taken to ensure that the existence of the reserves raised in this way does not allow distortion of the premia away from their representation of the true riskiness of a country's debt issuance policy, for example by subsidising the premia of high risk small countries with low per capita incomes. The purpose of the premia is to induce the countries to choose appropriate levels of debt.

It should be clear that with finite reserves, there remains a positive, if small, probability that the mutual insurance fund could not be able to meet all claims. In this case, the mutual insurance fund could ask for additional funds from non-defaulting countries.

\section{Institutional Issues of a Eurozone Default Risk Pool (EDRP)}

On the basis of the analysis in Section 2 we propose that the European Monetary Union (EMU) establishes an EDRP - a mutual insurance fund for dealing with sovereign default risk. The first step in the direction of this important new institution will be to formulate a treaty that establishes it and sets out the details of how it would operate. As a mutual insurance contract the treaty has to include, at a minimum, the following elements: identification of participating parties, the particular subject and risk covered, subjects and risks not covered (exclusions), the period of coverage, amounts of coverage, premia, the periodicity of premia, rules of conduct, penalties for misconduct, and the procedures in case of dispute. Clearly it is beyond the scope of this paper to formulate in detail such a treaty, but we find it useful to make the following points on the basis of the analysis in the previous sections. ${ }^{4}$

\subsection{Participation of Eurozone Countries}

The participating parties are all those countries in the Eurozone, although it could be argued that the EDRP should also be open to the other member states of the European Union. On the one hand, as interest rates in the European Union were quite heterogeneous before the euro was introduced, and the interest rate convergence after its introduction took place primarily for euro area countries and much less for other member states, the problem of sovereign debt default seems to concern the Eurozone rather than the European Union as a whole. On the other hand, there are external effects on all European Union countries arising from a default of one or more non-euro area countries and, under the mutual insurance system, what matters is the projected debt creation of the country concerned rather than monetary policy per se. It should also be noted however that there would be an element of foreign exchange risk that does not apply within the Eurozone. Probably the best approach would be to restrict at least initially membership to Eurozone countries with the possibility, once the insurance pool is tried and tested, to extend it to other European Union

\footnotetext{
${ }^{4}$ For more details see Arnold (2014), Chapter 10.
} 
countries. At the same time, membership of the EDRP should be a necessary condition of membership of the Eurozone: A country that did not accept the insurance premia implied by its proposed debt policy should be required to leave the Eurozone. Obviously, risk neutral countries would be unwilling to pay a fair premium if there were a positive probability of a bailout ex post.

\subsection{Full Insurance}

If a Eurozone country is likely to default due to a productivity shock, it receives an indemnity from the EDRP sufficient to pay off its insured debt, so that there is no haircut for the investors in its insured bonds.

\subsection{Fair Premia}

In exchange for the full insurance of debt, a Eurozone country would pay in advance a non-refundable premium which is calculated by the EDRP as being equal to the expected value of the total claim the country would make. Thus a country which has an almost zero probability of default would pay a premium of almost zero. Premia depend on the countries' prospective issuance of debt. Therefore each country is required to submit its proposed debt creation plan sufficiently in advance of the point in time at which cover commences to allow the EDRP to calculate the appropriate premium. Any subsequent debt creation in excess of that stated will only be covered by an extension of the indemnity if an additional premium, specified by the EDRP, is paid at or before the time the debt is created. Otherwise the debt increase is not covered by the insurance and investors in that debt must reckon with a haircut in case of default. Further, such additional debt will be junior to that covered by the indemnity. As a rule a country's actual debt creation should not however exceed that specified in its initial insurance proposal. We would argue that the existence of the EDRP and the contractual nature of its activities will make credible what is in effect a "no-bailout" clause. Politically, it should be easier for the European Union to refuse bailouts to countries that have violated this aspect of the operations of the Eurozone.

\subsection{Periodical Premia}

Premia are agreed upon and paid at regular intervals, most likely annually. This is because, given the proposed debt creation, the probabilities of default and therefore the insurance premia will depend on likely macroeconomic shocks (as expressed by $\theta_{i}$ in the theoretical model) and this creates the need for frequent review of the insurance contract. The process can be made to fit in with the timing of the countries' own national budgeting cycles. 


\subsection{Necessary Institutions}

To take due account of the principle of subsidiarity, which states that a matter should be handled by the least centralised authority capable of addressing that matter efficiently, we would argue that the choice of the level of debt creation should be left to the individual countries. If premia are determined on this choice and the system overall is credible, countries will choose the optimal levels of new debt in their own interest. Importantly, this implies that fiscal policies remain to be determined at the national level and thus the EMU does not have to be extended into a fiscal union.

Given a country's proposed level of debt creation, the calculation of default probabilities will be essentially a technical matter involving a short run macroeconomic forecast of likely shocks, and their translation into default probabilities of individual countries. In contrast to our theoretical model, it is unlikely that default risks of these countries are entirely statistically independent. They are more likely to be positively correlated, possibly with a complex system of crosscorrelations among countries, and so the risk calculations will necessarily be more complex than those we have presented in our model, though certainly not beyond the capacity of the actuaries who work in the insurance sector. It does imply however that the EDRP should be an agency staffed by experts in economics, statistics, insurance and finance. The EDRP should be regarded as a technically competent mutual insurance pool rather than as a bailout agency subject to political control.

We do not anticipate moral hazard issues in respect of the insurance offered by the EDRP. This is because the issue of debt by sovereign governments is fully observable. We suggested above how issuance of debt in excess of the amounts on which the insurance premia are calculated can be dealt with. Essentially, the EDRP offers no indemnity for defaults on such debt.

\subsection{The Role of Private Insurance Markets}

Although desirable for a market economy, the role of providing insurance against sovereign default risk - that in our proposal is assigned to the EDRP - cannot be completely fulfilled by private insurance markets.

Without the legal framework obligating the countries to hold insurance, thereby providing an institutional commitment to no bailouts, the countries (and investors) would not be receptive to adequate insurance premia, instead hoping for bailouts. As long as there is a non-zero probability of a bailout ex ante, a country would not be prepared to pay a fair premium for insurance. The whole idea of the insurance proposal is that the insurance scheme effectively acts as a commitment device to make bailouts unnecessary. Note that this is also the reason why a private insurance solution has not appeared spontaneously in the Eurozone yet. Although countries and investors have certainly had some possibilities to insure themselves against sovereign default risk in private insurance markets, e.g. by buying Credit Default Swaps, they have not used them to a sufficient extent. 


\section{The Proposed Alternatives to a Mutual Insur- ance Pool}

The Eurozone crisis has of course stimulated considerable discussion and debate, as well as a number of proposed solutions to deal with the future problem of sovereign default risk in Europe. The approach of this paper has been based on the view that the problem is essentially one of risk management, and that a mutual insurance system organised and run by the Eurozone countries is the most appropriate solution. Here we present the alternative proposals and discuss them in the light of our insurance-based approach.

\subsection{The European Stability Mechanism (ESM)}

The ESM was created as a permanent rescue fund for the Eurozone with the aim of providing emergency financial assistance to euro area member states in financial distress under strict conditionality. Financial assistance comprises loans, credit lines, loans for the purpose of re-capitalisation of financial institutions, and sovereign securities purchased either in the primary or secondary market. Conditionality depends on the financial assistance instrument chosen and may range from a macroeconomic adjustment programme to continuous respect of pre-established eligibility conditions, negotiated between the troika-consisting of the European Commission, the European Central Bank (ECB) and the International Monetary Fund - and the ESM member concerned. Its compliance is also monitored by the troika. Pricing depends on the financial assistance instrument chosen and covers the financing and operating costs including an appropriate margin. In order to be able to provide financial assistance, the ESM raises funds by issuing financial instruments or by entering into financial or other agreements or arrangements with ESM members, financial institutions or other third parties. The initial maximum lending volume of the ESM is set at 500 billion euro and its capital stock at 700 billion euro. Each country is liable in the amount of its share in the ECB's capital. Only 80 billion of the capital stock will be paid in; the remaining share can be called in the event of credit losses. $^{5}$

The ESM differs from the EDRP in two important respects. Firstly, countries do not have to pay an ex ante insurance premium. Since the investors in their bonds will be repaid capital plus interest, they do not require an interest rate risk premium. Thus at the time debt creation decisions are taken countries have no concrete incentive to take account of the default risk they may be entering into. Secondly, a country that faces default on its debt may or may not choose to request aid under the system. If it does so, it is envisaged to pay for the aid ex post by repaying the aid plus interest. If it does not do so and simply defaults, it avoids the cost of repaying the aid. Therefore, if it does claim the aid, this must be in the expectation that it will not repay the aid. We are then in exactly the same situation that has characterised the recent sovereign debt

\footnotetext{
${ }^{5}$ European Council (2012).
} 
crisis. Ex ante, it is believed that there will be a bailout, and this reinforces the likelihood that ex post there will indeed be one. The advantage of the EDRP with compulsory insurance ex ante is that it provides the incentive to take into account the risk of default when borrowing decisions are being made.

\subsection{Eurobonds}

Eurobonds are government bonds which are guaranteed by the euro area member states either severally, or jointly and severally. The guarantee means that if a euro area member state is not able to service the Eurobonds it has issued, the investors can request repayment plus interest from all other member states. "Severally" means that euro area member states are only liable for a part of the Eurobonds, e.g. in relation to their size; "jointly and severally" means that they can also be charged for the part of the debts of other member states if these default. Eurobonds differ from the ESM in that defaulting euro area member states have neither to repay the bailout costs plus interest nor to compensate the other euro area countries in any other manner. They may therefore lead to even higher debt accumulation of countries as well as higher losses. These risks will be priced into the bonds implying that low risk, fiscally responsible countries will be compensating high risk, fiscally irresponsible countries with corresponding moral hazard problems. Clearly, Eurobonds provide no kind of solution to the risk management problem whatsoever.

\subsection{Blue and Red Bonds}

Von Weizsäcker and Delpla (2010) distinguish between two types of government bonds: blue bonds which are issued under joint and several liability of European Union member states as senior debt, and red bonds which are issued as national and junior debt. They propose that European Union member states are allowed to issue up to 60 percent of their national debt as blue bonds and that any debt beyond this must be issued as red bonds. They expect that blue bonds will reduce the borrowing cost for this part of debt and that red bonds will increase the marginal cost of public borrowing which will enhance fiscal discipline, i.e. decrease debt levels, and mitigate the increase in the marginal cost of public borrowing.

Obviously, blue bonds are nothing other than Eurobonds and the von Weizsäcker/ Delpla proposal will have the effects they describe, rather than the effects described for Eurobonds, only if the limit of 60 percent is credible, i.e. if countries do indeed have to issue red bonds once they exceed this limit. We join Sinn $(2012)^{6}$ and Dübel $(2011)^{7}$ in doubting that this will be the case, and expect rather that as soon as the 60 percent level is reached the limit will be extended due to political pressure. Again, the facts that insurance premia are risk-based and paid by the Eurozone countries ex ante are the key to their effectiveness.

\footnotetext{
${ }^{6}$ Sinn, H.-W. (2012), pp. 347-9.

${ }^{7}$ Dübel, J. (2011), p. 2.
} 
Setting up an EDRP can be regarded as an institutional commitment to no bailouts on the part of the Eurozone.

\subsection{Debt Repayment Fund}

In 2011, the German Council of Economic Experts proposed the creation of a debt repayment fund with joint and several liability of European Union member states in which debt that exceeds the Maastricht Treaty reference value of 60 percent of GDP is outsourced. The outsourcing of debt is not to happen all at once, but successively within a period of about five years (roll-in-phase) in the course of outstanding debt repayment and new borrowing until the funding framework is fully used. Countries are required to repay their outsourced debt within a period of between 20 and 25 years according to a previously specified consolidation path. Debt that is not outsourced is to be contained by the introduction of national "debt brakes". 8

The proposal of the German Council of Economic Experts can be seen as a variant of the von Weizsäcker/Delpla proposal. Debt that is outsourced in the debt repayment fund is obviously comparable to the blue bonds or Eurobonds and debt that is not outsourced to the red bonds. Accordingly, the same criticism applies. As Sinn $(2012)^{9}$ argues, it is to be expected that as soon as the roll-in-phase is over, the contingent component of the debt repayment fund will be extended due to political pressure.

\subsection{Stability Bonds}

Also in 2011, the European Commission put forward a proposal to introduce so-called stability bonds, which would be issued jointly by the euro area member states. Its green paper lists three options based on the degree of substitution of national issuance and the nature of the underlying guarantee: full substitution with joint and several guarantees, partial substitution with joint and several guarantees, and partial substitution with several but not joint guarantees ${ }^{10}$.

The first option is equivalent to Eurobonds and the second similar to the proposals of blue/red bonds and a debt repayment fund, even though the European Commission does not state a specific level or share of debt that would be covered by stability bonds. Therefore, the same analysis applies and stability bonds have to be considered as leading to excessive debt accumulation.

\subsection{Partial Sovereign Bond Insurance by the ESM}

Dübel (2011) proposes to partially insure sovereign bonds under the ESM by dividing them in two parts: a predetermined uninsured part that is treated as junior debt, spun off as a marketable bond on the ESM application day and

\footnotetext{
${ }^{8}$ Sachverständigenrat zur Begutachtung der gesamtwirtschaftlichen Entwicklung (2011), Chapter 3.VI.

${ }^{9}$ Sinn, H.-W. (2012), pp. 349f.

${ }^{10}$ European Commission (2011), p. 12.
} 
subject to a haircut, and the insured part that is treated as senior debt and amortised as scheduled.

According to Dübel, the difference between his proposal and the blue bond proposal is that the marginal cost of partially insured debt would have a floor while the marginal cost of uninsured red bonds would explode in a financial crisis, thereby driving a country out of the bond market and into the ESM. Since the ESM does nothing other than issue blue bonds, all sovereign bonds would have to be assumed to be blue bonds which would result in moral hazard, as discussed above.

While we share Dübel's assessment of the blue/red bond proposal, we doubt that his proposal will be the optimal alternative. Even if it succeeded in avoiding panic in the market, it would not achieve the optimal result since it is the ESM that provides the partial insurance, with the undesirable effects on debt accumulation discussed above.

\subsection{EEAG Crisis Mechanism}

In its tenth report on the European economy, the European Economic Advisory Group (EEAG) proposes a crisis mechanism that distinguishes between various stages of crisis and differentiates the degree of help the European Union should provide to a member country according to the stage of crisis that it faces. It suggests that the higher the stage of crisis that a country has reached the lower the degree of help by the European Union should be. Concretely, the crisis mechanism distinguishes between three stages of crisis-illiquidity, pending insolvency and actual insolvency - and proposes the following measures by the European Union at the various stages:

- At the stage of illiquidity the European Union should provide short-term loans without creditors participating in losses, which in the end is equivalent to a full bailout by the European Union.

- In contrast, at the stage of actual insolvency a country should restructure its entire outstanding debt without the European Union providing any help whatsoever, so that creditors are made to participate in losses through haircuts.

- At the interim stage of pending insolvency the European Union should provide some help while creditors should bear limited losses. The concrete proposal is that the European Union offers replacement bonds that it partially guarantees in exchange for maturing bonds after a limited haircut on these bonds has taken place. It is important that at this stage it is not the total outstanding debt that is at stake but only the debt that is maturing. Debt that will mature later is not subject to a haircut and not involved in the exchange for replacement bonds. The question of whether this debt can be serviced in the regular way or also needs to face a haircut and be converted is postponed to its maturity date. 
This breakwater procedure involves solving the payment problems step by step as they emerge. However, for it to work Collective Action Clauses need to be included in debt contracts that permit a majority agreement of creditors whose debt matures in a particular point in time that becomes generally binding for them, without owners of debt instruments with other maturities being able to call in their claims prematurely. ${ }^{11}$

Our EDRP model as we have presented it above deals with only one of these three stages of crisis, namely actual insolvency. Since the EEAG proposes to leave the countries on their own at the stage of actual insolvency, it is essentially arguing for a credible no-bailout policy, which shall be achieved by the downward graduation of aid with the stage of crisis. Thereby, similar to the previous proposals, the EEAG proposal overlooks incentives to the contrary when the stage of actual insolvency is in fact reached. We expect that if the actual insolvency of countries is imminent, the EMU will be willing to grant bailouts despite affirmations to the contrary.

The EEAG proposal can however be incorporated into our model. There is nothing to say that the events insured against could not consist of illiquidity or pending insolvency, this is really a matter of the scale on which ex post a sovereign debt crisis occurs. The premium at which full indemnity for all insured events, including illiquidity or merely "pending insolvency", can be offered will then depend on the probabilities of all those events. Again, the main point is that, unlike our insurance proposal, the EEAG proposal and indeed all others do not meet the need for ex ante provision of incentive to choose debt levels that keep down the probability of occurrence of the events being insured against.

\section{Conclusion}

In its short history, the Eurosystem has proved to be faulty in design. It has shown a failure of risk management that culminated in the current Eurozone crisis and several conflicting measures taken by European Union leaders and the ECB to deal with the consequences of this crisis.

Under the assumption that the provisions of the Maastricht Treaty will be respected, the initial assessment that the "regime" would prevent sovereign defaults from emerging, and therefore would not need a risk management system, may have been justified. After France and Germany caused the provisions to fail, it should however have been clear that some mechanism for dealing with sovereign default was going to be necessary.

As long as the environment was stable, the system could work despite increasing debt levels. The Global Financial Crisis however created a huge disturbance and triggered sovereign defaults to happen.

In this paper we argued that the gap in design can be filled by setting up a mutual insurance fund for dealing with sovereign default risk. Within the framework of a model, in which the benevolent governments of a monetary union decide on sovereign debt before risk neutral agents choose asset portfolios

${ }^{11}$ European Economic Advisory Group (2011), Chapter 2. 
consisting of these debts and risk free assets, we showed that the equilibrium in the benchmark case of a credible no-bailout policy - characterised by optimal levels of debt - can be replicated by establishing a mutual insurance fund; insurance premia replace the interest rate risk premia that investors would require if the threat of no bailouts was fully credible.

We further concretised the idea of introducing a mutual insurance fund in the EMU as a means to cope with sovereign defaults in the proposal of a Eurozone default risk pool. We argued for initially restricting membership of the pool to Eurozone countries (with the possibility to later extend it to other European countries), explained how the determination of debt issuance and premiums can be made to fit in with the timing of the countries' own national budgeting cycles, and pointed to the importance of leaving the choice of the level of debt creation to the individual countries and creating the pool as a technically competent body independent of political influence.

Finally, we discussed the proposals of the European Stability Mechanism, Eurobonds, a distinction between blue and red bonds, debt repayment funds, stability bonds, partial sovereign bond insurance by the ESM, and the EEAG proposal of a multistage crisis mechanism in the light of our insurance-based approach. We found that, unlike our proposal of a mutual insurance pool, all these proposals are missing ex ante provision of incentive to take into account the costs of default risk that countries create by their debt choice, therefore bringing about disincentives of excessive debt accumulation.

\section{Acknowledgements}

We would like to thank Gerhard Illing, Kenneth Kletzer, Richard Peter, HansWerner Sinn and Christoph Trebesch as well as conference participants at the Annual Conference of the Association for Public Economic Theory in Lisbon and the Annual Congress of the International Institute of Public Finance in Taormina for helpful comments and suggestions. 


\section{References}

[1] Arnold, N. K. A. (2014), The Sovereign Default Problem in the Eurozone. Why limited liability resulted in excessive debt accumulation and how insurance can counteract, University of Munich.

[2] Beetsma, R. M. W. J. and A. L. Bovenberg (1999), "Does Monetary Unification Lead to Excessive Debt Accumulation?," Journal of Public Economics 74, 299-325.

[3] Beetsma, R., and H. Uhlig (1999), "An Analysis of the Stability and Growth Pact," Economic Journal 109, 546-71.

[4] Chari, V. V.and P. J. Kehoe (2007), "On the Need for Fiscal Constraints in a Monetary Union," Journal of Monetary Economics 54, 2399-408.

[5] Chari, V. V. and P. J. Kehoe (2008), "Time Inconsistency and Free-Riding in a Monetary Union," Journal of Money, Credit and Banking 40, 1329-56.

[6] Cooper, R. and H. Kempf. (2004), "Overturning Mundell: Fiscal Policy in a Monetary Union," Review of Economic Studies 71, 371-96.

[7] Cooper, R., H. Kempf and D. Peled (2008), "Is It Is or Is It Ain't My Obligation? Regional Debt in a Fiscal Federation," International Economic Review 49, 1469-504.

[8] Cooper, R., H. Kempf and D. Peled (2010), "Regional Debt in Monetary Unions: Is It Inflationary?," European Economic Review 54, 345-58.

[9] Crivelli, C. and K. Staal (2013), "Size, Spillovers and Soft Budget Constraints," International Tax and Public Finance 20, 338-56.

[10] Dübel, H.-J. (2011), "Partial Sovereign Bond Insurance by the Eurozone: A More Efficient Alternative to Blue (Euro-)bonds," CEPS Papers 5999, Centre for European Policy Studies.

[11] European Commission (2011), "GREEN PAPER on the feasibility of introducing Stability Bonds," COM(2011) 818 final, Brussels, http://ec.europa.eu/commission_20102014/president/news/documents/pdf/green_en.pdf.

[12] European Economic Advisory Group (2011), The Report on the European Economy, CESifo, Munich, https://www.cesifo-group.de/DocDL/EEAG2011.pdf.

[13] European Council (2012), Treaty Establishing the European Stability Mechanism, http://www.european-council.europa.eu/media/582311/05tesm2.en12.pdf.

[14] Goodspeed, T. (2002), "Bailouts in a Federation," International Tax and Public Finance 9, 409-21. 
[15] Inada, K.-I. (1963), "On a Two-Sector Model of Economic Growth: Comments and a Generalization," The Review of Economic Studies 30 (2), 119127.

[16] Sachverständigenrat zur Begutachtung der Gesamtwirtschaftlichen Entwicklung (2011), Verantwortung für Europa wahrnehmen. Jahresgutachten 2011/12, Bonifatius GmbH Buch-DruckVerlag, Paderborn, Http://www.sachverstaendigenratwirtschaft.de/fileadmin/dateiablage/download/gutachten/ga11_ges.pdf.

[17] Sinn, H.-W. (2012), Die Target Falle. Gefahren für unser Geld und unsere Kinder, Carl Hanser Verlag, Munich.

[18] Uhlig, H. (2003), "One Money, but Many Fiscal Policies in Europe: What Are the Consequences?," in: M. Buti, ed., Monetary and Fiscal Policies in EMU Interactions and Coordination, Cambridge University Press.

[19] von Weizsäcker, J. and J. Delpla (2010), "The Blue Bond Proposal," Policy Briefs 403, Bruegel.

[20] Wildasin, D. E. (1997), "Externalities and Bailouts," The World Bank Development Research Group, Policy Research Working Paper No. 1843, November. 